\title{
New Rhodium Pyridylphosphine Complexes and Their Application in Hydrogenation Reactions
}

\author{
Albert S. C. Chan,* Chih-Chiang Chen, and Rong Cao \\ Union Laboratory of Asymmetric Synthesis and Department of Applied Biology and Chemical \\ Technol ogy, The Hong Kong Polytechnic University, Hong Kong \\ Maw-Rong Lee \\ Department of Chemistry, National Chung Hsing University, Taiwan \\ Shie-Ming Peng and Gene Hsiang Lee \\ Department of Chemistry, National Taiwan University, Taiwan
}

Recei ved J anuary $8,1997^{\circledR}$

\begin{abstract}
New phosphine ligands containing substituted pyridyl rings, namely tris[3-(2,6-dimethoxypyridyl)]phosphine (1), bis[3-(2,6-dimethoxypyridyl)]phenylphosphine (2), and 3-(2,6dimethoxypyridyl)diphenyl phosphine (3), have been prepared. The purpose was to overcome previous problems associated with the use of pyridylphosphine ligands in catalytic hydrogenation reactions and to devel op a new class of catalysts that can be separated from reaction mediums via phase separation. To prevent the formation of polymeric transitionmetal complexes of pyridyl phosphines (which took place via the coordination of the $\mathrm{P}$ and $\mathrm{N}$ atoms of the ligands to separate metal centers), the ortho-hydrogen atoms of the pyridyl rings were replaced with more bulky substituents. The use of methoxy substituents at the ortho positions of the pyridyl ring in this new class of pyridylphosphine ligands successfully prevented the coordination of the pyridyl group to the metal center and al lowed the formation of discrete rhodium pyridylphosphine complexes, which were found to be active in the catalytic hydrogenation of ol efins, aldehydes, and imines. The solubility of these rhodium pyridylphosphine complexes in organic solvent or in aqueous solution can be altered by adjusting the acidity of the solution. The separation of the catalyst from the reaction product in a water-immiscible organic solvent was achieved by extracting the catalyst with hydrochloric acid. Upon neutralization of the aqueous extract with sodium carbonate, the catalyst could be re-extracted into an organic layer and could be reused in a new batch of hydrogenation reaction with similar reactivity as the freshly prepared complexes.
\end{abstract}

\section{Introduction}

One of the most important breakthroughs in thestudy of homogeneous catalysis in the past three decades is the development of rhodium organophosphine catalysts for hydrogenation and hydroformylation reactions. In 1965, Wilkinson et al. and Coffey independently developed chlorotris(triphenyl phosphine)rhodium as a facile catalyst for the catalytic hydrogenation of olefins. ${ }^{1-3}$ Further development of this chemistry by Wilkinson et al. and Pruett et al. resulted in the successful commercial application of $\mathrm{HRh}(\mathrm{CO})\left(\mathrm{PPh}_{3}\right)_{3}$ as a catalyst precursor in the hydroformylation of propene. ${ }^{4}$ The development of rhodium chiral phosphine complexes created an exciting, new field of research: homogeneous catalytic asymmetric hydrogenation. The Monsanto L-Dopa process based on the asymmetric hydrogenation of an enamide catalyzed by $\mathrm{Rh}$ (dipamp) ${ }^{+}$was successfully commercialized in the mid-1970's. ${ }^{5}$ The substantial interest in this area has been reflected in the

${ }^{\otimes}$ Abstract published in Advance ACS Abstracts, J uly 1, 1997.

(1) Young, J . F.; Osborn, J . A.; J ardine, F. H.; Wilkinson, G. J . Chem. Soc. Chem. Commun. 1965, 131.

(2) Osborn, J . A.; J ardine, F. H.; Young, J . F .; Wilkinson, G. J . Chem. Soc. A 1966, 1711 .

(3) Coffey, R. S. Brit. Pat. 1,121,642 (assigned to ICI), filed in 1965.

(4) Pruett, R. L. Adv. Organomet. Chem. 1979, 17, 1. thousands of publications on the use of transition-metal phosphine catalysts in the literature in the past three decades.

As an effort to further develop the arylphosphine ligands and their application in homogeneous catalysis, transition-metal complexes containing pyridylphosphine ligands have been synthesized and tested in catalytic hydrogenation, ${ }^{6}$ hydroformylation, ${ }^{6-8}$ and carbonylation reactions. ${ }^{9-11}$ The potential advantages of using a pyridyl ring to replace a phenyl ring in the arylphosphine ligands are that (1) the added functional ity of the pyridyl group in the ligand may introduce more interesting chemistry and (2) the solubility of the new ligands, either in aqueous or in organic solvents, may be easily controlled simply by adjusting the acidity of the solution. (The latter property may be useful for the separation of the catalyst from the products via phase

(5) Knowles, W. S. Acc. Chem. Res. 1983, 16, 106.

(6) Kurtev, K.; Ribola, D.; J ones, R. A.; Cole-Hamilton, D. J .; Wilkinson, G. J . Chem. Soc., Dalton Trans. 1980, 55.

(7) Fell, B.; Papadogianakis, G. J . Mol. Catal. 1991, 66, 143.

(8) Gladiali, S.; Pinna, L.; Arena, C. G.; Rotondo, E., Faraone, F.J Mol. Catal. 1991, 66, 183.

(9) Drent, E.; Budzelaar, P. H. M.; J ager, W. W. Eur. Pat. Appl. EP386,833; Chem. Abstr. 1991, 114, 142,679z.

(10) Drent, E.; Budzelaar, P. H. M. Eur. Pat. Appl. EP386,834; Chem. Abstr. 1991, 114, 142,680t.

(11) Zao, W.-J .; Fang,T.-Q.; Zhang, S.-Q.; Zhang, Z.-Z.; Yang, L.-M J . Chem. Eng. Natural Gas 1992, 17, 3. 
separation. The use of sulfonated triphenylphosphine as a water-soluble organophosphine ligand has found successful commercial application in the Rh-catalyzed hydroformylation of olefin. ${ }^{12}$ ) Unfortunately, in the previous studies the metal complexes containing pyridyl phosphine ligands were found to be inactive in the hydrogenation of olefins. ${ }^{6}$ This was thought to be due to the coordination of the nitrogen atom of the pyridyl ring to the metal center and saturated the coordination sites. In this paper, we wish to report the results of a new approach to the pyridyl phosphine ligands and their application in homogeneous hydrogenation reactions.

\section{Results and Discussion}

The synthesis of pyridyl phosphines has recently been reviewed by Newkome. ${ }^{13}$ Previous studies mostly focused on the added binding capability of the pyridyl group in the organophosphine species. ${ }^{13-15}$ In this study, we intentionally avoided the coordination of the pyridyl ring by limiting the access of the nitrogen atom to the metal center via the use of more hindered groups to replace the ortho hydrogen atoms. An initial attempt with methoxy substituents at the ortho positions has been found to be successful. When 2,6-dimethoxypyridine was lithiated with n-butyllithium in THF at -40 ${ }^{\circ} \mathrm{C}$ followed by the slow addition of phosphorus trichloride at the same temperature, tris[3-(2,6-dimethoxypyridyl)]phosphine (1) was obtained. The recrystallization<smiles>COc1cccc(OC)n1</smiles>
$\underline{1}$

of the crude product from ethanol gave a $45 \%$ yield of pure tris[3-(2,6-dimethoxypyridyl)]phosphine.

Similarly, pure bis[3-(2,6-dimethoxypyridyl)]phenylphosphine (2) and 3-(2,6-dimethoxypyridyl)di phenylphosphine (3) were obtained in $70 \%$ and $45 \%$ yields, respectively, by reacting the lithiated 2,6-dimethoxypyridine with dichlorophenyl phosphine and chlorodiphenyl phosphine, respectively.

Like triphenylphosphine, all three of these substituted pyridylphosphine ligands can be used to make discrete transition-metal complexes without the complication of the coordination of the pyridyl ring. For example, when $[\mathrm{Rh}(\mathrm{COD}) \mathrm{Cl}]_{2}(\mathrm{COD}=1,5$-cyclooctadiene) was allowed to react with 2 equiv of these ligands, discrete, monomeric $[R h C l(C O D) \cdot L(L=\mathbf{1}, \mathbf{2}$, or $\mathbf{3})$ was obtained. The molecular structure of $[\mathrm{RhCl}(\mathrm{COD}) \cdot 2]$ was unambiguously characterized by single-crystal $X$ ray diffraction as a square planar complex. A perspective view of this complex is shown in Figure 1 . The relevant crystal data, bond lengths, and bond angles are summarized in Tables $1-3$. It was noted that C(3) and $C(8)$ of the COD ligand had higher thermal parameters in the X-ray study. This is not uncommon in ethylene groups and may be due to some conformational disorder.

(12) Kuntz, E. G. Chemtech 1987, Sep, 570.

(13) Newkome, G. R. Chem. Rev. 1993, 93, 2067

(14) Yang, H.; Alvarez, M.; Lugan, N.; Mathieu, R. J . Chem. Soc., Chem. Commun. 1995, 1721.

(15) Brunner, H.; Bublak, P. Synthesis 1995, 36.

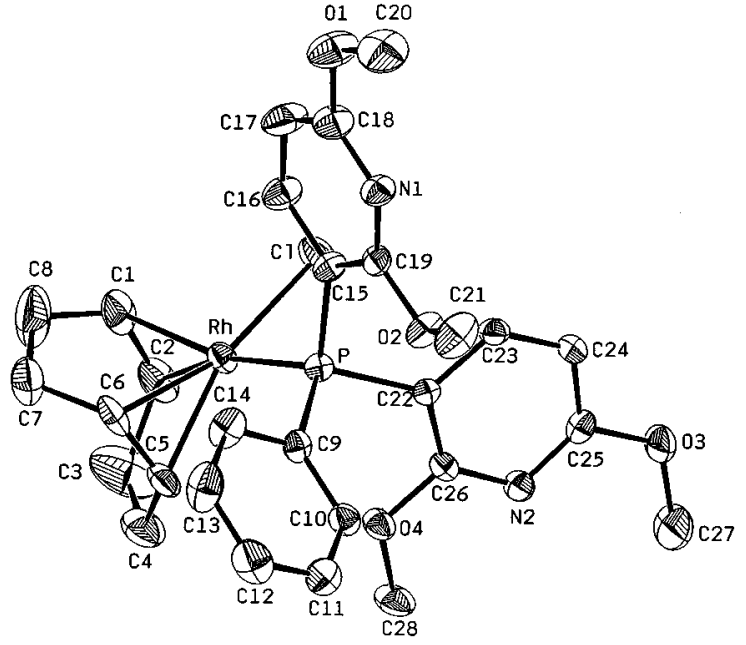

Figure 1. ORTEP drawing of $\left[\mathrm{RhCl}\left(\mathrm{C}_{8} \mathrm{H}_{12}\right) \cdot 2\right]$ with $30 \%$ ellipsoid.

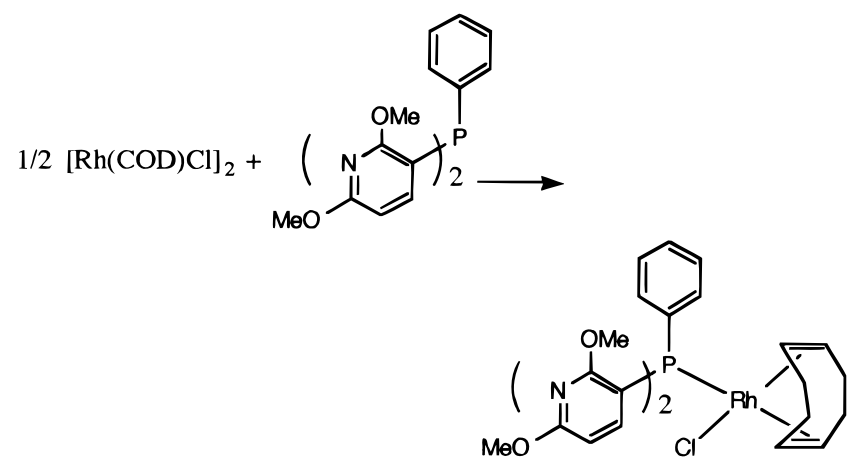

Unlike the regular pyridylphosphinerhodium complexes that are inactive in hydrogenation reactions, these new types of pyridylphosphine complexes are good catalysts for the hydrogenation of olefins, aldehydes, and imines. At ambient temperature and under 200 psig of $\mathrm{H}_{2}$, the catalysts are not active in the hydrogenation of ketones. When a conjugated eno ketone is subjected to hydrogenation with these catalysts, only the $\mathrm{C}=\mathrm{C}$ double bond is hydrogenated. Several typical examples of the catalytic hydrogenation reactions are listed in Table 4.

An obvious added dimension of the new pyridylphosphine ligands (versus triphenylphosphine) is the controllable sol ubility, either in organic solvent or in water, via the control of the acidity of the solution. This property offers an opportunity for phase separation of the transition-metal catalysts containing these ligands from the water-immiscible organic medium and, therefore, may facilitate the recycling of the transitionmetal-phosphine catalysts. In this regard, we tested the rhodium catalyst containing $\mathbf{1}$ in hydrogenation reactions in benzene followed by the extraction of the catalyst with $12 \mathrm{~N}$ hydrochloric acid. Atomic absorption studies of the aqueous and the organic layers indicated that $96 \%$ of the catalyst was extracted into the aqueous layer. A ${ }^{31}$ P NMR study indicated that the catalyst was intact during the extraction process and the acidified catalyst could be re-extracted from the aqueous solution with a water-immiscible organic solvent (e.g., benzene or toluene) after the neutralization of the $\mathrm{HCl}$ with a base. These results clearly shed light on the potential benefits for the further development of this type of new ligands and catalysts. 
Table 1. Crystal Data and Conditions for Crystallographic Data Collection and Structure Refinementa

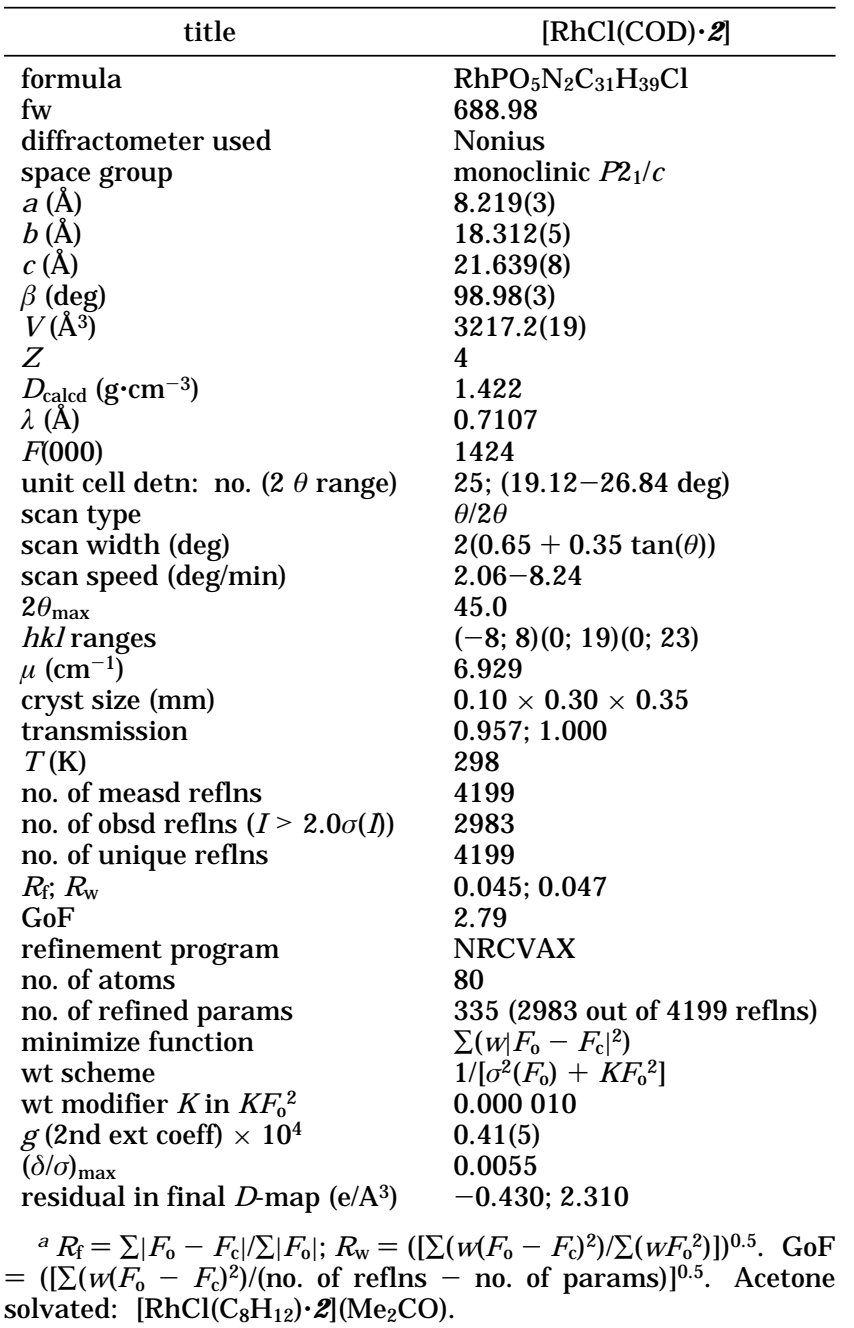

Table 2. Bond Distances $(\AA)$ of $\left[R h C l\left(C_{8} \mathrm{H}_{12}\right) \cdot 2\right]$

$\begin{array}{llll}\mathrm{Rh}-\mathrm{Cl} & 2.3617(23) & \mathrm{C} 15-\mathrm{C} 16 & 1.390(11) \\ \mathrm{Rh}-\mathrm{P} & 2.3183(22) & \mathrm{C} 15-\mathrm{C} 19 & 1.393(11) \\ \mathrm{Rh}-\mathrm{C} 1 & 2.204(8) & \mathrm{C} 16-\mathrm{C} 17 & 1.379(12) \\ \mathrm{Rh}-\mathrm{C} 2 & 2.221(8) & \mathrm{C} 17-\mathrm{C} 18 & 1.389(13) \\ \mathrm{Rh}-\mathrm{C} 5 & 2.121(8) & \mathrm{C} 18-\mathrm{N} 1 & 1.318(11) \\ \mathrm{Rh}-\mathrm{C} 6 & 2.144(8) & \mathrm{C} 18-\mathrm{O} 1 & 1.345(10) \\ \mathrm{P}-\mathrm{C} 9 & 1.839(8) & \mathrm{C} 19-\mathrm{N} 1 & 1.336(9) \\ \mathrm{P}-\mathrm{C} 15 & 1.812(8) & \mathrm{C} 19-\mathrm{O} 2 & 1.343(10) \\ \mathrm{P}-\mathrm{C} 22 & 1.823(7) & \mathrm{C} 20-\mathrm{O} 1 & 1.409(12) \\ \mathrm{C} 1-\mathrm{C} 2 & 1.349(14) & \mathrm{C} 21-\mathrm{O} 2 & 1.405(10) \\ \mathrm{C} 1-\mathrm{C} 8 & 1.517(15) & \mathrm{C} 22-\mathrm{C} 23 & 1.404(10) \\ \mathrm{C} 2-\mathrm{C} 3 & 1.498(14) & \mathrm{C} 22-\mathrm{C} 26 & 1.380(10) \\ \mathrm{C} 3-\mathrm{C} 4 & 1.483(16) & \mathrm{C} 23-\mathrm{C} 24 & 1.365(11) \\ \mathrm{C} 4-\mathrm{C} 5 & 1.482(12) & \mathrm{C} 24-\mathrm{C} 25 & 1.371(11) \\ \mathrm{C} 5-\mathrm{C} 6 & 1.377(13) & \mathrm{C} 25-\mathrm{N} 2 & 1.323(10) \\ \mathrm{C} 6-\mathrm{C} 7 & 1.514(13) & \mathrm{C} 25-\mathrm{O} 3 & 1.364(9) \\ \mathrm{C} 7-\mathrm{C} 8 & 1.451(15) & \text { C26-N2 } & 1.330(9) \\ \text { C9-C10 } & 1.361(11) & \text { C26-O4 } & 1.355(8) \\ \text { C9-C14 } & 1.373(11) & \text { C27-O3 } & 1.410(11) \\ \text { C10-C11 } & 1.369(11) & \text { C28-O4 } & 1.419(10) \\ \text { C11-C12 } & 1.369(13) & \text { O5-C29 } & 1.26(3) \\ \text { C12-C13 } & 1.370(14) & \text { C29-C30 } & 1.562(24) \\ \text { C13-C14 } & 1.414(12) & \text { C29-C31 } & 1.376(25)\end{array}$

In conclusion, in the design and synthesis of new pyridylphosphine ligands, we have been able to prepare substituted pyridylphosphine ligands that form discrete, well-defined rhodium complexes that are active in the catalytic hydrogenation of olefins, aldehydes, and imines. The phase separation of these catalysts from water-immiscible organic solvents with hydrochloric
Table 3. Bond Angles of $\left[\mathrm{RhCl}\left(\mathrm{C}_{8} \mathrm{H}_{12}\right) \cdot 2\right]$

\begin{tabular}{|c|c|c|c|}
\hline $\mathrm{Cl}-\mathrm{Rh}-\mathrm{P}$ & $87.45(8)$ & $\mathrm{P}-\mathrm{C} 9-\mathrm{C} 14$ & $116.3(6)$ \\
\hline $\mathrm{Cl}-\mathrm{Rh}-\mathrm{Cl}$ & $89.39(24)$ & $\mathrm{C} 10-\mathrm{C} 9-\mathrm{C} 14$ & $118.8(7)$ \\
\hline $\mathrm{Cl}-\mathrm{Rh}-\mathrm{C} 2$ & $90.99(24)$ & $\mathrm{C} 9-\mathrm{C} 10-\mathrm{C} 11$ & $121.8(7)$ \\
\hline $\mathrm{Cl}-\mathrm{Rh}-\mathrm{C} 5$ & $159.06(25)$ & $\mathrm{C} 10-\mathrm{C} 11-\mathrm{C} 12$ & $120.6(8)$ \\
\hline $\mathrm{Cl}-\mathrm{Rh}-\mathrm{C} 6$ & $162.7(3)$ & $\mathrm{C} 11-\mathrm{C} 12-\mathrm{C} 13$ & $118.8(8)$ \\
\hline $\mathrm{P}-\mathrm{Rh}-\mathrm{Cl}$ & $162.4(3)$ & $\mathrm{C} 12-\mathrm{C} 13-\mathrm{C} 14$ & $120.3(8)$ \\
\hline$P-R h-C 2$ & $161.8(3)$ & $\mathrm{C} 9-\mathrm{C} 14-\mathrm{C} 13$ & $119.6(8)$ \\
\hline $\mathrm{P}-\mathrm{Rh}-\mathrm{C} 5$ & $93.94(24)$ & $\mathrm{P}-\mathrm{C} 15-\mathrm{C} 16$ & $120.5(6)$ \\
\hline$P-R h-C 6$ & $96.91(23)$ & $\mathrm{P}-\mathrm{C} 15-\mathrm{C} 19$ & $123.3(6)$ \\
\hline $\mathrm{C} 1-\mathrm{Rh}-\mathrm{C} 2$ & $35.5(4)$ & C16-C15-C19 & $115.8(7)$ \\
\hline $\mathrm{C} 1-\mathrm{Rh}-\mathrm{C} 5$ & $95.2(3)$ & C15-C16-C17 & $120.4(8)$ \\
\hline $\mathrm{C} 1-\mathrm{Rh}-\mathrm{C} 6$ & $81.4(3)$ & $\mathrm{C} 16-\mathrm{C} 17-\mathrm{C} 18$ & $117.9(8)$ \\
\hline $\mathrm{C} 2-\mathrm{Rh}-\mathrm{C} 5$ & $81.2(3)$ & $\mathrm{C} 17-\mathrm{C} 18-\mathrm{N} 1$ & $123.9(7)$ \\
\hline $\mathrm{C} 2-\mathrm{Rh}-\mathrm{C} 6$ & $89.9(3)$ & $\mathrm{C} 17-\mathrm{C} 18-\mathrm{O} 1$ & $116.6(8)$ \\
\hline $\mathrm{C} 5-\mathrm{Rh}-\mathrm{C} 6$ & $37.7(3)$ & $\mathrm{N} 1-\mathrm{C} 18-\mathrm{O} 1$ & $119.5(7)$ \\
\hline $\mathrm{Rh}-\mathrm{P}-\mathrm{C} 9$ & $118.70(24)$ & $\mathrm{C} 15-\mathrm{C} 19-\mathrm{N} 1$ & $125.1(7)$ \\
\hline $\mathrm{Rh}-\mathrm{P}-\mathrm{C} 15$ & $113.8(3)$ & C15-C19-O2 & $117.0(6)$ \\
\hline $\mathrm{Rh}-\mathrm{P}-\mathrm{C} 22$ & $110.19(23)$ & $\mathrm{N} 1-\mathrm{C} 19-\mathrm{O} 2$ & $117.9(7)$ \\
\hline $\mathrm{C} 9-\mathrm{P}-\mathrm{C} 15$ & $101.2(3)$ & $\mathrm{P}-\mathrm{C} 22-\mathrm{C} 23$ & $122.2(5)$ \\
\hline $\mathrm{C} 9-\mathrm{P}-\mathrm{C} 22$ & $106.3(3)$ & $P-C 22-C 26$ & $121.9(5)$ \\
\hline $\mathrm{C} 15-\mathrm{P}-\mathrm{C} 22$ & $105.4(3)$ & $\mathrm{C} 23-\mathrm{C} 22-\mathrm{C} 26$ & $115.4(6)$ \\
\hline $\mathrm{Rh}-\mathrm{C} 1-\mathrm{C} 2$ & $72.9(5)$ & $\mathrm{C} 22-\mathrm{C} 23-\mathrm{C} 24$ & $120.3(7)$ \\
\hline $\mathrm{Rh}-\mathrm{C} 1-\mathrm{C} 8$ & $107.5(6)$ & $\mathrm{C} 23-\mathrm{C} 24-\mathrm{C} 25$ & $117.7(7)$ \\
\hline $\mathrm{C} 2-\mathrm{C} 1-\mathrm{C} 8$ & $125.4(9)$ & C24-C25-N2 & $125.1(7)$ \\
\hline $\mathrm{Rh}-\mathrm{C} 2-\mathrm{C} 1$ & $71.6(5)$ & $\mathrm{C} 24-\mathrm{C} 25-\mathrm{O} 3$ & $116.8(7)$ \\
\hline $\mathrm{Rh}-\mathrm{C} 2-\mathrm{C} 3$ & $109.1(6)$ & $\mathrm{N} 2-\mathrm{C} 25-\mathrm{O} 3$ & $118.1(7)$ \\
\hline $\mathrm{C} 1-\mathrm{C}_{2}-\mathrm{C} 3$ & $125.7(9)$ & $\mathrm{C} 22-\mathrm{C} 26-\mathrm{N} 2$ & $125.8(6)$ \\
\hline $\mathrm{C} 2-\mathrm{C} 3-\mathrm{C} 4$ & $116.8(8)$ & $\mathrm{C} 22-\mathrm{C} 26-\mathrm{O} 4$ & $116.7(6)$ \\
\hline $\mathrm{C} 3-\mathrm{C} 4-\mathrm{C} 5$ & $115.1(8)$ & $\mathrm{N} 2-\mathrm{C} 26-\mathrm{O} 4$ & $117.5(6)$ \\
\hline $\mathrm{Rh}-\mathrm{C} 5-\mathrm{C} 4$ & $111.3(6)$ & C18-N1-C19 & $116.9(7)$ \\
\hline $\mathrm{Rh}-\mathrm{C} 5-\mathrm{C} 6$ & $72.1(5)$ & $\mathrm{C} 25-\mathrm{N} 2-\mathrm{C} 26$ & $115.6(6)$ \\
\hline $\mathrm{C} 4-\mathrm{C} 5-\mathrm{C} 6$ & $126.0(8)$ & $\mathrm{C} 18-01-\mathrm{C} 20$ & $117.2(7)$ \\
\hline $\mathrm{Rh}-\mathrm{C} 6-\mathrm{C} 5$ & $70.3(5)$ & C19-O2-C21 & $118.8(6)$ \\
\hline $\mathrm{Rh}-\mathrm{C} 6-\mathrm{C} 7$ & $112.0(6)$ & $\mathrm{C} 25-\mathrm{O} 3-\mathrm{C} 27$ & $117.6(6)$ \\
\hline $\mathrm{C} 5-\mathrm{C} 6-\mathrm{C} 7$ & $125.8(8)$ & $\mathrm{C} 26-\mathrm{O} 4-\mathrm{C} 28$ & $117.9(6)$ \\
\hline $\mathrm{C} 6-\mathrm{C} 7-\mathrm{C} 8$ & $115.8(8)$ & O5-C29-C30 & $83.7(15)$ \\
\hline $\mathrm{C} 1-\mathrm{C} 8-\mathrm{C} 7$ & $116.9(9)$ & O5-C29-C31 & $95.0(16)$ \\
\hline $\mathrm{P}-\mathrm{C} 9-\mathrm{C} 10$ & $124.9(6)$ & C $30-C 29-C 31$ & $113.4(15)$ \\
\hline
\end{tabular}

Table 4. Examples of the Homogeneous Hydrogenation Reactions Catalyzed by [RhCl(COD)·1]

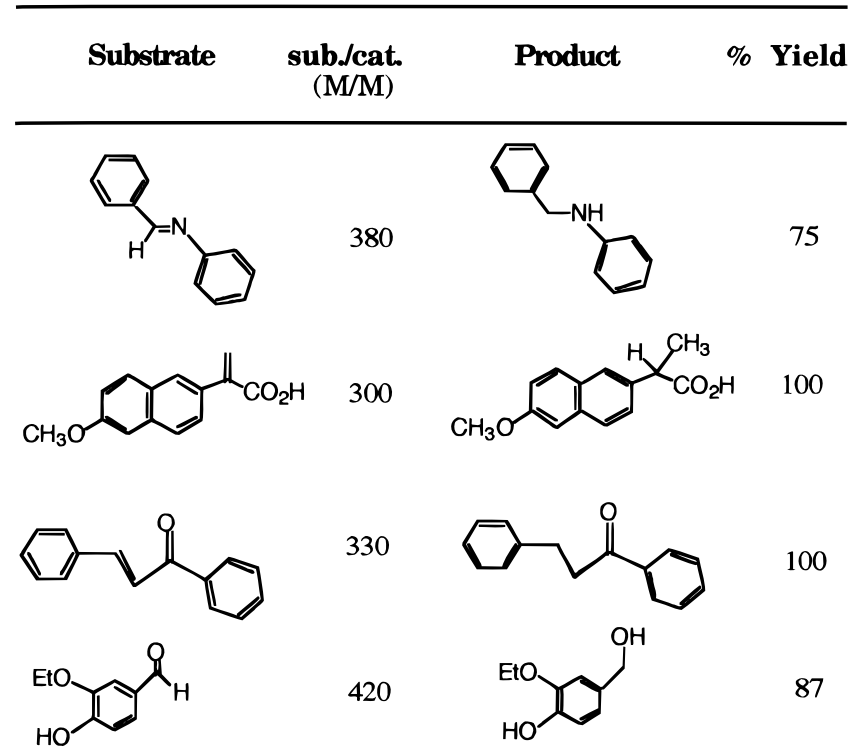

a Reaction conditions: $25^{\circ} \mathrm{C}$; 200 psig of $\mathrm{H}_{2}$; substrate/cat. (wt) $=100$; quantitative sel ectivity was obtained in all cases (therefore, the percentage of conversion was the same as the percentage of yield).

acid also has been achieved. Further development of this type of substituted pyridyl phosphine ligands, particularly in chiral forms, is in good progress.

\section{Experimental Section}

General Methods and Procedures. Unless otherwise indicated, all experiments were carried out under nitrogen 
atmosphere. All NMR data were recorded on a Bruker DPX400 instrument. The high-resolution mass spectrometry was carried out on a JEOL JMS SX/SX 102A four-sector tandem mass spectrometer. Purchased reagents were used as received, and all solvents were dried and distilled before use.

Tris[3-(2,6-dimethoxypyridyl)]phosphine (1). A solution of n-butyllithium ( $6.25 \mathrm{~mL}$ of a $1.6 \mathrm{M}$ hexane solution, 10 $\mathrm{mmol}$ ) was slowly added to a solution of 2,6-dimethoxypyridine $(1.39 \mathrm{~g}, 10 \mathrm{mmol})$ in $20 \mathrm{~mL}$ of THF at $-40^{\circ} \mathrm{C}$ under magnetic stirring over a period of about $1 \mathrm{~h}$. After all the $\mathrm{n}$-butyllithium was added, the mixture continued to stir for $1 \mathrm{~h}$ at $-40{ }^{\circ} \mathrm{C}$ and $4 \mathrm{~h}$ at ambient temperature. The solution was cooled to $-40{ }^{\circ} \mathrm{C}$ again, and $0.28 \mathrm{~mL}$ of $\mathrm{PCl}_{3}(3.3 \mathrm{mmol})$ in $10 \mathrm{~mL}$ of THF was added dropwise to it while stirring was continued. The solution was brought to ambient temperature, and $2 \mathrm{~mL}$ of water was added to quench the reaction. The solvent was evaporated in a rotary evaporator, and the residue was redissolved in $30 \mathrm{~mL}$ of chloroform. The chloroform solution was washed with $30 \mathrm{~mL}$ of water and dried over anhydrous sodium sulfate. Evaporation of the solvent in vacuo gave a crude material that was recrystallized from ethanol to give $0.667 \mathrm{~g}$ of a white powdery product (45\% theoretical yield). ${ }^{1} \mathrm{H}$ NMR in $\mathrm{CDCl}_{3} \delta: 3.84\left(\mathrm{~s}, 9 \mathrm{H}, \mathrm{OCH}_{3}\right) ; 3.91\left(\mathrm{~s}, 9 \mathrm{H}, \mathrm{OCH}_{3}\right) ; 6.22(\mathrm{~d}$, $\left.3 \mathrm{H}, \mathrm{J}_{\mathrm{H}-\mathrm{H}}=8.1 \mathrm{~Hz}\right) ; 6.95\left(\mathrm{dd}, 3 \mathrm{H}, \mathrm{J}_{\mathrm{H}-\mathrm{H}}=8.1 \mathrm{~Hz}, \mathrm{~J}_{\mathrm{P}-\mathrm{H}}=4.1\right.$ $\mathrm{Hz}) .{ }^{13} \mathrm{C}[\mathrm{H}] \mathrm{NMR}$ in $\mathrm{CDCl}_{3} \delta: 53.24\left(\mathrm{OCH}_{3}\right) ; 106.43(\mathrm{~d}, \mathrm{~J} \mathrm{p}-\mathrm{C}$ $=13.5 \mathrm{~Hz}, \mathrm{C}-3$ ); 144.53 (C-4); 101.25 (C-5); 163.81 (C-2 and C-6; could not be resolved on a DPX400 NMR). ${ }^{31} P[H]$ NMR in $\mathrm{CDCl}_{3}: \delta:-47.67 \mathrm{ppm}$. Molecular weight according to high-resolution mass spectrometry (EI): 445.1401 (calcd molecular weight $=445.1400$; error $=0.1 \mathrm{mmu}$.) Anal. Calcd for $\mathrm{C}_{21} \mathrm{H}_{24} \mathrm{O}_{6} \mathrm{~N}_{3} \mathrm{P}$ : C, 56.63; $\mathrm{H}$, 5.43. Found: C, 56.29; $\mathrm{H}, 5.41$.

Bis[3-(2,6-dimethoxypyridyl)]phenylphosphine (2). A solution of $n$-butyllithium $(6.25 \mathrm{~mL}$ of a $1.6 \mathrm{M}$ hexane solution, $10 \mathrm{mmol}$ ) was slowly added to a solution of 2,6-dimethoxypyridine $(1.39 \mathrm{~g}, 10 \mathrm{mmol})$ in $20 \mathrm{~mL}$ of $\mathrm{THF}$ at $-40{ }^{\circ} \mathrm{C}$ under magnetic stirring over a period of about $1 \mathrm{~h}$. After all the n-butyllithium was added, the mixture continued to stir for 1 $\mathrm{h}$ at $-40{ }^{\circ} \mathrm{C}$ and $4 \mathrm{~h}$ at ambient temperature. The solution was cooled to $-40{ }^{\circ} \mathrm{C}$ again, and $0.68 \mathrm{~mL}$ of dichlorophenyl phosphine ( $5 \mathrm{mmol}$ ) in $10 \mathrm{~mL}$ of THF was added dropwise to it while the stirring was continued. The solution was brought to ambient temperature, and $2 \mathrm{~mL}$ of water was added to quench the reaction. The solvent was evaporated in a rotary evaporator, and the residue was redissolved in $30 \mathrm{~mL}$ of chloroform. The chlor oform solution was washed with $30 \mathrm{~mL}$ of water and dried over anhydrous sodium sulfate. Evaporation of the solvent in vacuo gave a crude material that was recrystallized from ethanol to give $1.34 \mathrm{~g}$ of white powdery product (70\% theoretical yield). ${ }^{1} \mathrm{H} \mathrm{NMR}$ in $\mathrm{CDCl}_{3}$, pyridyl rings $\delta 3.84\left(\mathrm{~s}, 6 \mathrm{H}, \mathrm{OCH}_{3}\right) ; 3.91\left(\mathrm{~s}, 6 \mathrm{H}, \mathrm{OCH}_{3}\right) ; 6.22(\mathrm{~d}, 2 \mathrm{H}$, $\left.\mathrm{J}_{\mathrm{H}-\mathrm{H}}=8.2 \mathrm{~Hz}\right), 6.94\left(\mathrm{dd}, 2 \mathrm{H}, \mathrm{J}_{\mathrm{H}-\mathrm{H}}=8.1 \mathrm{~Hz}, \mathrm{~J}_{\mathrm{P}-\mathrm{H}}=4.5 \mathrm{~Hz}\right)$; phenyl ring $\delta: 7.23-7.30(\mathrm{~m}, 5 \mathrm{H}) .{ }^{13} \mathrm{C}[\mathrm{H}] \mathrm{NMR}$ in $\mathrm{CDCl}_{3}$, pyridyl rings $\delta: 53.49\left(\mathrm{OCH}_{3}\right) ; 107.62(\mathrm{~d}, \mathrm{~J} \mathrm{P}-\mathrm{C}=12.7 \mathrm{~Hz}, \mathrm{C}-3)$; 145.40 (C-4); 101.58 (C-5); 162.26 (C-2 and C-6; could not be resolved on a DPX400 NMR); phenyl ring $\delta$ : 127.91, 128.22, 128.37, 128.48, 133.37 (d, J $\mathrm{P}-\mathrm{C}=21.1 \mathrm{~Hz}$ ). ${ }^{31} \mathrm{P}[\mathrm{H}] \mathrm{NMR}$ in $\mathrm{CDCl}_{3} \delta:-35.47 \mathrm{ppm}$. Molecular weight according to highresolution mass spectrometry (EI) 384.1234 (calcd molecular weight $=384.1239$; error $=0.5 \mathrm{mmu}$.) Anal. Calcd for $\mathrm{C}_{20} \mathrm{H}_{21} \mathrm{O}_{4} \mathrm{~N}_{2} \mathrm{P}$ : C, 62.50; $\mathrm{H}, 5.51$. Found: C, 62.50; $\mathrm{H}, 5.50$.

3-(2,6-Dimethoxypyridyl)diphenylphosphine (3). A solution of $n$-butyllithium $(6.25 \mathrm{~mL}$ of a $1.6 \mathrm{M}$ hexane solution, $10 \mathrm{mmol}$ ) was slowly added to a solution of 2,6-dimethoxypyridine $(1.39 \mathrm{~g}, 10 \mathrm{mmol})$ in $20 \mathrm{~mL}$ of THF at $-40{ }^{\circ} \mathrm{C}$ under magnetic stirring over a period of about $1 \mathrm{~h}$. After all the n-butyllithium was added, the mixture was continued to stir for $1 \mathrm{~h}$ at $-40{ }^{\circ} \mathrm{C}$ and $4 \mathrm{~h}$ at ambient temperature. The solution was cooled to $-40{ }^{\circ} \mathrm{C}$ again, and $1.8 \mathrm{~mL}$ of chlorodiphenylphosphine ( $10 \mathrm{mmol}$ ) in $10 \mathrm{~mL}$ of THF was added dropwise to it while the stirring was continued. The solution was brought to ambient temperature, and $2 \mathrm{~mL}$ of water was added to quench the reaction. The solvent was evaporated in a rotary evaporator, and the resi due was redissolved in $30 \mathrm{~mL}$ of chloroform. The chloroform solution was washed with 30 $\mathrm{mL}$ of water and dried over anhydrous sodium sulfate. Evaporation of the solvent in vacuo gave a crude material that was recrystallized from ethanol to give $1.45 \mathrm{~g}$ of white powdery product (45\% theoretical yield). ${ }^{1} \mathrm{H} N M R$ in $\mathrm{CDCl}_{3}$, pyridyl ring $\delta: 3.88\left(\mathrm{~s}, 3 \mathrm{H}, \mathrm{OCH}_{3}\right) ; 3.92\left(\mathrm{~s}, 3 \mathrm{H}, \mathrm{OCH}_{3}\right) ; 6.22(\mathrm{~d}, 1 \mathrm{H}$, $\left.\mathrm{J}_{\mathrm{H}-\mathrm{H}}=8.2 \mathrm{~Hz}\right) ; 6.92\left(\mathrm{dd}, 1 \mathrm{H}, \mathrm{J}_{\mathrm{H}-\mathrm{H}}=8.2 \mathrm{~Hz}, \mathrm{~J}_{\mathrm{P}-\mathrm{H}}=4.5 \mathrm{~Hz}\right)$; phenyl rings $\delta:(\mathrm{m}, 10 \mathrm{H}) .{ }^{13} \mathrm{C}[\mathrm{H}] \mathrm{NMR}$ in $\mathrm{CDCl}_{3}$, pyridyl ring $\delta$ : 53.59 and $53.71\left(\mathrm{OCH}_{3}{ }^{\prime} \mathrm{s}\right) ; 108.45\left(\mathrm{~d}, \mathrm{~J}_{\mathrm{P}-\mathrm{C}}=12.5 \mathrm{~Hz}, \mathrm{C}-3\right)$; 145.57 (C-4); 101.77 (C-5); 164.07 (C-2); 164.32 (C-6); phenyl ring $\delta$ : $128.45,133.53,136.60\left(\mathrm{~d}, \mathrm{~J}_{\mathrm{P}-\mathrm{C}}=10.6 \mathrm{~Hz}\right) .{ }^{31} \mathrm{P}[\mathrm{H}] \mathrm{NMR}$ in $\mathrm{CDCl}_{3} \delta:-21.97 \mathrm{ppm}$. Molecular weight according to highresolution mass spectrometry (EI): 323.1083 (calcd molecular weight $=323.1075$; error $=0.8 \mathrm{mmu}$.) Anal. Calcd for $\mathrm{C}_{19} \mathrm{H}_{18} \mathrm{O}_{2} \mathrm{NP}$ : C, 70.58; $\mathrm{H}$, 5.61. Found: C, 70.28; $\mathrm{H}, 5.63$.

[RhCl(C $\left.\left.\mathbf{C}_{8} \mathbf{H}_{12}\right) \cdot \mathbf{2}\right] .\left[\mathrm{Rh}(\mathrm{COD}) \mathrm{Cl}_{2}(50 \mathrm{mg}, 0.1 \mathrm{mmol})\right.$ and $\mathbf{2}$ ( $77 \mathrm{mg}, 0.2 \mathrm{mmol}$ ) were stirred in $5 \mathrm{~mL}$ of benzene in a $25 \mathrm{~mL}$ round-bottom flask at ambient temperature for $1 \mathrm{~h}$. The solvent was evaporated in vacuo, and a yellow residue was collected. NMR studies indicated that the reaction was essentially quantitative, and the product was used for catalytic reactions. ${ }^{1} \mathrm{H} N M R$ in $\mathrm{CDCl}_{3}$, coordinated COD $\delta: 1.95,2.02$ (m, 8H, $\mathrm{CH}_{2}$ 's); 5.33 (b, 4H, CH's of COD); substituted pyridyl $\delta: 3.92\left(\mathrm{~s}, 3 \mathrm{H}, \mathrm{OCH}_{3}\right) ; 3.94\left(\mathrm{~s}, 3 \mathrm{H}, \mathrm{OCH}_{3}\right) ; 6.35(\mathrm{~d}, 1 \mathrm{H}, \mathrm{J} \mathrm{H}-\mathrm{H}=$ $8.1 \mathrm{~Hz}) ; 6.96(\mathrm{~b})$; phenyl $\delta$ : $7.27(\mathrm{~m}, 1 \mathrm{H}), 7.37(\mathrm{~m}, 2 \mathrm{H}), 8.05$ (dd, $2 \mathrm{H}, \mathrm{J} \mathrm{H}-\mathrm{H}=8.5 \mathrm{~Hz}, \mathrm{~J}_{\mathrm{P}-\mathrm{H}}=10.7 \mathrm{~Hz}$ ). ${ }^{13} \mathrm{C}[\mathrm{H}] \mathrm{NMR}$ in $\mathrm{CDCl}_{3}$ : coordinated COD $\delta$ : 29.00, $33.05\left(\mathrm{CH}_{2}{ }^{\prime} \mathrm{s}\right) ; 70.65,70.78$ (CH's); substituted pyridyl $\delta$ : 101.47, 103.02 (d, J $\mathrm{p}-\mathrm{C}=48 \mathrm{~Hz}$ ), 148.86, 163.22, 165.22; phenyl $\delta$ : 127.48, 128.87, 132.03, $131.23\left(\mathrm{~d}, \mathrm{~J}_{\mathrm{P}-\mathrm{C}}=44.5 \mathrm{~Hz}\right)$. ${ }^{31} \mathrm{P}[\mathrm{H}] \mathrm{NMR}$ in $\mathrm{CDCl}_{3} \delta: 14.43(\mathrm{~d}$, $\mathrm{J}_{\mathrm{Rh}-\mathrm{P}}=148.5 \mathrm{~Hz}$ ). Molecular weight according to highresolution mass spectrometry (FAB): 630.0928 (calculated molecular weight $=630.0921$; error $=0.7 \mathrm{mmu}$.)

$[\mathrm{RhCl}(\mathrm{COD}) \cdot \mathbf{1}]$ and $[\mathrm{RhCl}(\mathrm{COD}) \cdot 3]$ were prepared similarly.

Catalytic Hydrogenation. A typical procedure for the catalytic hydrogenation of unsaturated substrates is as follows. A $50 \mathrm{~mL}$ stainless steel autoclave equipped with a magnetic stirring bar was charged with $1.0 \mathrm{mg}$ of $\left[\mathrm{RhCl}\left(\mathrm{C}_{8} \mathrm{H}_{12}\right) \cdot \mathbf{1}\right], 100$ $\mathrm{mg}$ of substrate, and $5 \mathrm{~mL}$ of methanol under $1 \mathrm{~atm}$ of nitrogen gas. The autoclave was then pressurized with 200 psig of $\mathrm{H}_{2}$, and the solution was stirred at ambient temperature for $16 \mathrm{~h}$. $\mathrm{The}_{2}$ was released at the end of the reaction, and the solution was transferred to a $50 \mathrm{~mL}$ round-bottom flask. The solvent was evaporated in vacuo, and the residue was analyzed by ${ }^{1} \mathrm{H}$ NMR and/or HPLC.

Test of the Phase Separation of Catalyst from the Organic Product. In a typical experiment, a $50 \mathrm{~mL}$ autoclave with a glass liner and a magnetic stirring bar was charged with $0.4 \mathrm{mg}$ of $[\mathrm{RhCl}(\mathrm{COD}) \cdot \mathbf{1}]$ in $2 \mathrm{~mL}$ of toluene and $20 \mathrm{mg}$ of benzylideneacetophenone. The autoclave was pressurized with 200 psig of $\mathrm{H}_{2}$, and the solution was stirred under $\mathrm{H}_{2}$ pressure at ambient temperature for $15 \mathrm{~h}$. The $\mathrm{H}_{2}$ gas was released, and the organic solution was extracted with $2 \mathrm{~mL}$ of $12 \mathrm{~N} \mathrm{HCl}$ solution twice. The aqueous layer was diluted to $50 \mathrm{~mL}$ with distilled water and was analyzed for rhodium content with a Varian Model 1200 atomic absorption spectrometer using the rhodium atomic spectral line at $343.5 \mathrm{~nm}$. A total of $96.2 \%$ of the rhodium complex was found in the aqueous layer.

Test of the Integrity of the Catalyst during Phase Separation. [RhCl(COD) -1] $(2.0 \mathrm{mg})$ was dissolved in $0.4 \mathrm{~mL}$ of deuterated benzene, and the 31P NMR of the species was recorded. ( ${ }^{31} \mathrm{P}[\mathrm{H}] \mathrm{NMR}$ in $\mathrm{C}_{6} \mathrm{D}_{6} \delta: \delta 8.48, \mathrm{~d}, \mathrm{~J} \mathrm{Rh}-\mathrm{P}=151.7 \mathrm{~Hz}$.) The solution was extracted with $0.4 \mathrm{~mL}$ of $12 \mathrm{~N}$ hydrochloric acid, the aqueous layer was collected and a ${ }^{31} \mathrm{P}$ NMR of the aqueous solution was recorded. ( ${ }^{31} \mathrm{P}[\mathrm{H}] \mathrm{NMR}$ in $\mathrm{H}_{2} \mathrm{O} \delta$ : 10.65 , $\mathrm{d}, \mathrm{J}_{\mathrm{Rh}-\mathrm{P}}=150.8 \mathrm{~Hz}$.) The acidic aqueous solution was neutralized with aqueous sodium carbonate solution, and the solution was extracted with $5 \mathrm{~mL}$ of toluene. The organic layer was separated, and the toluene solvent was evaporated in vacuo. 
The residue was redissolved in $0.4 \mathrm{~mL}$ of deuterated benzene, and a final ${ }^{31} \mathrm{P} N M R$ was recorded. ( ${ }^{31} \mathrm{P}[\mathrm{H}] \mathrm{NMR}$ in $\mathrm{C}_{6} \mathrm{D}_{6} \delta$ : 8.45, d, J Rh-P = 151.4 Hz.)

Test of Catalyst Recycle. In a typical experiment, a 50 $\mathrm{mL}$ stainless steel autodave equipped with a magnetic stirring bar was charged with $2 \mathrm{~mL}$ of toluene, $5 \mathrm{mg}$ of 2-(6-methoxy2-naphthyl)acrylic acid (substrate), and $0.05 \mathrm{mg}$ of [RhCl(COD)•(1) (catalyst precursor). The autoclave was pressurized

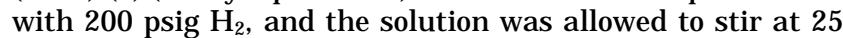
${ }^{\circ} \mathrm{C}$ under 200 psig of of $\mathrm{H}_{2}$ for $4 \mathrm{~h}$. The hydrogen was released under an inert atmosphere $\left(\mathrm{N}_{2}\right)$. A small sample of the solution was taken for HPLC analysis, and $84 \%$ of the substrate was found to be hydrogenated to give 2-(6-methoxy2-naphthyl)propanoic acid. The solution was extracted with $4 \mathrm{~mL}$ of $12 \mathrm{~N} \mathrm{HCl}$ solution. After phase separation, the aqueous layer was titrated with $1 \mathrm{~N} \mathrm{Na}_{2} \mathrm{CO}_{3}$ solution until the solution just turned basic (according to a litmus paper test). The catalyst was extracted from the aqueous layer with 10 $\mathrm{mL}$ of toluene that, after phase separation, was concentrated to $2 \mathrm{~mL}$ by evaporating off the excess solvent in vacuo. The resulting solution and $5 \mathrm{mg}$ of 2-(6-methoxy-2-naphthyl)acrylic acid (substrate) was charged to the autoclave, and the hydrogenation reaction was carried out again under identical conditions for $4 \mathrm{~h}$. Product analysis after releasing the $\mathrm{H}_{2}$ indicated $80 \%$ of the 2-(6-methoxy-2-naphthyl)acrylic acid was hydrogenated to give the 2-(6-methoxy-2-naphthyl)propanoic acid product.
Crystallography. A crystal of dimensions $0.1 \times 0.30 \times$ $0.35 \mathrm{~mm}$ was used for data collection on an Enraf-Nonius diffractometer (graphite monochromatized Mo $\mathrm{K} \alpha$ radiation, $\lambda=0.7107)$ using the $\theta-2 \theta$ scan method $\left(2 \theta_{\max }=45^{\circ}\right)$ at 298 $K$. Intensity data were corrected for Lorentz and polarization effects; empirical absorptions were based on $\Psi$ scans. A total of 4199 unique reflections were obtained, 2983 of which were considered observed $(\mathrm{I}>2 \sigma(\mathrm{I}))$ and used in structure refinement. The structure was solved by Patterson and refined by full-matrix least-squares methods using the NRCVAX program. ${ }^{16}$ The final least-squares refinement was calculated with 335 parameters and converged to $R_{F}=4.5 \%, R_{W F}=4.7 \%$, and $\mathrm{S}=2.79$ with $\mathrm{W}^{-1}=\sigma^{2}(\mathrm{~F})+0.00001 \mathrm{~F}^{2}$. The hydrogen atoms were placed in idealized positions and were not refined. The bond lengths and bond angles are listed in Tables 2 and 3 , respectively.

Acknowledgment. We thank the Research Grant Council of Hong Kong for financial support of this study.

Supporting Information Available: Tables of atomic parameters and $U$ values (4 pages). Ordering information is given on any current masthead page.

\section{$\mathrm{OM} 970010 \mathrm{H}$}

(16) Gabe, E. J .; Le Page, Y.; Charland, J . P.; Lee, F. L.; White, P. S. J. Appl. Crystallogr. 1989, 22, 384. 